CLINICAL STUDY

\title{
Congenital IGF1 deficiency tends to confer protection against post-natal development of malignancies
}

\author{
Rachel Steuerman ${ }^{1}$, Orit Shevah ${ }^{1}$ and Zvi Laron ${ }^{1,2}$ \\ ${ }^{1}$ Endocrinology and Diabetes Research Unit, Schneider Children's Medical Center, 14 Kaplan Street, Petah Tikva 49202, Israel and ${ }^{2}$ WHO Collaborating \\ Center for the Study of Diabetes in Youth, and Sackler Faculty of Medicine, Tel Aviv University, Tel Aviv, Israel \\ (Correspondence should be addressed to Z Laron at Endocrinology and Diabetes Research Unit, Schneider Children's Medical Center; \\ Email: laronz@clalit.org.il)
}

\begin{abstract}
Objective: To investigate whether congenital IGF1 deficiency confers protection against development of malignancies, by comparing the prevalence of malignancies in patients with congenital (secondary) deficiency of IGF1 with the prevalence of cancer in their family members.

Method: Only patients with an ascertained diagnosis of either Laron syndrome (LS), congenital IGHD, congenital multiple pituitary hormone deficiency (cMPHD) including GH or GHRHR defect were included in this study. In addition to our own patients, we performed a worldwide survey and collected data on a total of 538 patients, 752 of their first-degree family members, of which 274 were siblings and 131 were further family members.

Results: We found that none of the 230 LS patients developed cancer and that only 1 out of 116 patients with congenital IGHD, also suffering from xeroderma pigmentosum, had a malignancy. Out of 79 patients with GHRHR defects and out of 113 patients with congenital MPHD, we found three patients with cancer in each group.

Among the first-degree family members (most heterozygotes) of LS, IGHD and MPHD, we found 30 cases of cancer and 1 suspected. In addition, 31 malignancies were reported among 131 further relatives.

Conclusions: Our findings bear heavily on the relationship between GH/IGF1 and cancer. Homozygous patients with congenital IGF1 deficiency and insensitivity to GH such as LS seem protected from future cancer development, even if treated by IGF1. Patients with congenital IGHD also seem protected.
\end{abstract}

European Journal of Endocrinology 164 485-489

\section{Introduction}

Linked to their proliferative, differentiation and apoptotic properties, both $\mathrm{GH}$ and insulin-like growth factor 1 (IGF1) have been identified as risk factors for certain malignancies (1-5), even in the pediatric age group and young adults (6-8). There is also evidence that most tumors and transformed cells display increased IGF1 receptor (IGF-1R) concentration and high IGF1R mRNA, causing enhanced IGF1 binding $(9,10)$, leading to the axiom that overexpression of IGF1R is a pre-requirement for acquisition or progress of malignant tumors (11). Further evidence for the link between GH, IGF1 and cancer is the successful use of GH and IGF-1R-blocking agents in the treatment of malignancy (12). The above findings led us to investigate the reverse situation, namely whether congenital defects of GH and IGF1 action would diminish or prevent the development of cancer.

In 2007, we reported preliminary data on 169 patients with Laron syndrome (LS) and on 250 of their first- and second-degree relatives and found that none of the homozygous LS patients had developed cancer, whereas $24 \%$ of their heterozygous family members had (13). We also showed that 35 patients with congenital (c) IGHD and 18 with GHRH receptor (R) mutation reported no malignancies. In contradiction, 9-24\% of their family members had a history of cancer.

The aim of the present study was to extend our findings by enlarging the number of patients with LS and cIGHD and to collect data on patients with GHRHR mutations and congenital multiple pituitary hormone deficiency (cMPHD), including GH.

\section{Methods}

This retrospective study was approved by the ethics committee. The following procedures were employed to collect the data:

a. We updated data from our medical charts of LS patients, which had increased to 67 and, 28 patients were with cIGHD.

b. Sent questionnaires to authors of published reports on patients with the diagnoses mentioned. 
c. Approached personally the physicians from countries we knew there are patients with the above diseases.

Out of the several hundreds of questionnaires sent, we received replies from over 80 colleagues. The limitations found in collecting the data were:

i. Some of the authors reporting the patients had performed only the genetic analysis and had no clinical information on the patients.

ii. Many of the patients live in small villages and countries inaccesible to the treatment, so patient follow-up was lost. Prevalence of cancer types could also not be obtained from these countries.

iii. Lack of cooperation.

\section{Statistical analysis}

The collected data were analysed using the BMDP statistical software (14). One-way and two-way ANOVA were used to analyse continuous variables (age) and as for discrete variables (diagnosis/type of malignancy), $\chi^{2}$ test and Fisher's Exact test were used. A $P$ value $<0.05$ was considered statistically significant.

\section{Subjects}

We were able to collect data on a total of 538 patients, 752 of their first-degree family members (parents, siblings and offspring) and 131 further family members. Only patients with the following ascertained diagnoses were included in this study:

i. LS - secondary congenital deficiency of IGF1 and primary GH insensitivity, due to defects in the GH receptor.

ii. Primary congenital isolated hGH deficiency (cIGHD).

iii. GHRHReceptor (R) defect - secondary hGH deficiency.

iv. Congenital multiple pituitary hormone deficiency, including hGH (cMPHD).

A high percentage of the LS, cIGHD and GHRHR patients underwent genetic molecular analysis. In most of the cMPHD patients, the diagnosis was based on clinical and endocrine evaluation. Unfortunately, the ages were not stated for all patients and relatives, nor was the age of diagnosis of malignancies stated in all questionnaires.

\section{Results}

Table 1 shows the number and age distribution of patients as well as that of the first-degree relatives, including siblings and further relatives in each diagnostic group. It is of note that we were able to collect data on half or more of the presumed total number of LS patients (not including the Ecuadorian

Table 1 Number and age of the patients and their relatives in four diagnostic groups with secondary congenital IGF1 deficiency.

\begin{tabular}{|c|c|c|c|c|c|}
\hline & \multicolumn{4}{|c|}{ Diagnostic groups } & \multirow[b]{2}{*}{ Total } \\
\hline & (GHR defects) & clGHD & GHRHR defect & cMPHD & \\
\hline \multicolumn{6}{|l|}{ Patients } \\
\hline Total number $(n)$ & 230 & 116 & 79 & 113 & 538 \\
\hline Number with known age & $166^{a}$ & $106^{\mathrm{b}}$ & $16^{\mathrm{c}}$ & $113^{d}$ & $401^{\mathrm{e}}$ \\
\hline Mean age \pm s.D. & $19.2 \pm 15$ & $18.3 \pm 12.8$ & $29.7 \pm 23$ & $29.4 \pm 18.7$ & $22.2 \pm 16.7$ \\
\hline \multicolumn{6}{|l|}{ First-degree relatives } \\
\hline Total number $(n)$ & 218 & 203 & 150 & 181 & 752 \\
\hline Number with known age & 157 & 200 & 12 & 173 & 542 \\
\hline Age range & $1-81$ & $1-84$ & $3-93$ & $1-84$ & $1-93$ \\
\hline Mean age \pm S.D. & $37.7 \pm 19.1$ & $32.2 \pm 19.1$ & $48 \pm 24$ & $31.4 \pm 18.5$ & $33.8 \pm 19.3$ \\
\hline \multicolumn{6}{|l|}{ Further relatives } \\
\hline Total number $(n)$ & 113 & 13 & 4 & 1 & 131 \\
\hline Age range & 29-85 & $28-83$ & $26-59$ & - & $26-85$ \\
\hline Mean age \pm S.D. & $61 \pm 14.7$ & $61.83 \pm 17.9$ & $43.2 \pm 17.1$ & - & $59.8 \pm 16$ \\
\hline \multicolumn{6}{|l|}{ Siblings only } \\
\hline Total number $(n)$ & 86 & 96 & 6 & 86 & 274 \\
\hline Number with known age & 65 & 95 & 6 & 83 & 249 \\
\hline Age range & $1-80$ & $1-81$ & $3-47$ & $1-56$ & $1-81$ \\
\hline Mean age \pm S.D. & $25.7 \pm 17.3$ & $22.2 \pm 19$ & $36.3 \pm 16.6$ & $19.2 \pm 13.3$ & $22.4 \pm 17$ \\
\hline \multicolumn{6}{|l|}{$P$ values } \\
\hline $\begin{array}{l}\text { Patients versus first-degree } \\
\text { relatives }\end{array}$ & $<0.001$ & $<0.001$ & 0.03 & 0.37 & $<0.001$ \\
\hline Patients versus siblings & 0.001 & 0.08 & 0.49 & $<0.001$ & 0.7 \\
\hline
\end{tabular}

Number of patients above 30 years: ${ }^{a} 31 ;{ }^{b} 19 ;{ }^{c} 6 ;{ }^{d} 51 ;{ }^{e} 107$. 
Table 2 The prevalence of malignancy in the four diagnostic groups.

\begin{tabular}{|c|c|c|c|c|c|}
\hline & \multicolumn{4}{|c|}{ Diagnostic groups } & \multirow[b]{2}{*}{ Total } \\
\hline & Laron sydrome & ClGHD & GHRHR defects & cMPHD & \\
\hline \multicolumn{6}{|l|}{ Patients } \\
\hline Total number $(n)$ & 230 & 116 & 79 & 113 & 538 \\
\hline Number of malignancies & 0 & $1^{\mathrm{b}}$ & $3^{\mathrm{c}}$ & $3^{\mathrm{d}}$ & 7 \\
\hline Prevalence of malignancy (\%) & 0.0 & 0.9 & 3.8 & 2.7 & 1.3 \\
\hline \multicolumn{6}{|l|}{ First-degree relatives } \\
\hline Total number $(n)$ & 218 & 203 & 150 & 181 & 752 \\
\hline Number of malignancies & $18(15)$ & $7(6)$ & 0 & $5+1^{a}(6)$ & $30(26+1)^{\mathrm{a}}$ \\
\hline Prevalence of malignancy (\%) & 8.3 & 3.4 & 0.0 & 2.8 & 4.0 \\
\hline \multicolumn{6}{|l|}{ Further relatives } \\
\hline Total number $(n)$ & 113 & 13 & 4 & 1 & 131 \\
\hline Number of malignancies & $25(24)$ & $4(4)$ & $1(1)$ & $1(1)$ & $31(30)$ \\
\hline Prevalence of malignancy (\%) & 22.1 & 30.8 & 25 & - & 23.7 \\
\hline \multicolumn{6}{|l|}{ Siblings only } \\
\hline Total number $(n)$ & 86 & 96 & 6 & 86 & 274 \\
\hline Number of malignancies & $5(4)$ & $2(2)$ & 0 & $2(2)$ & $9(80)$ \\
\hline Prevalence of malignancy (\%) & 5.8 & 2.1 & 0.0 & 2.3 & 3.3 \\
\hline \multicolumn{6}{|l|}{$P$ values } \\
\hline Patients versus first-degree relatives & $<0.001$ & 0.43 & 0.04 & 1 & 0.019 \\
\hline Patients versus further relatives & $<0.001$ & $<0.001$ & 0.182 & - & $<0.001$ \\
\hline Patients versus siblings & 0.005 & 0.59 & 1 & 1 & $<0.165$ \\
\hline
\end{tabular}

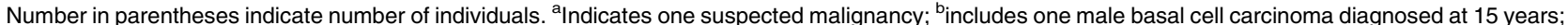
${ }^{c}$ includes one male Hodgkins lymphoma diagnosed at 43 years and two male skin cancers (one diagnosed at 37 years and the other unknown); ${ }^{\text {includes two }}$ female thyroid carcinoma diagnosed at 10.5 and 52 years and one male planocellular carcinoma of the nasal septum diagnosed at 66 years of age.

cohort) and probably a large percentage of those with GHRHR mutations.

In total, the patients were significantly younger than their first-degree relatives $(P<0.001)$, though the differences in the GHRHR defect and the cMPHD groups were not significant. Also, there was no significant age difference when we compared the age of patients with that of their siblings. It is worth mentioning that the patients' age range was wide, reaching 85 years, and that $25 \%$ of the patients with recorded age were above 30 years of age.

Table 2 shows the prevalence of malignancies in the patients and their relatives in each diagnostic group. It is seen that none of the $230 \mathrm{LS}$ patients had developed a malignancy, despite the fact that 66 had been or are still treated by IGF1 and two had received hGH as well. The difference between the prevalence of malignancies in all the first-degree relatives and that in the siblings alone, with that in the patients was significant $(P<0.001$, $P=0.005$, respectively). Out of the 116 patients with cIGHD, only one boy suffers from xeroderma pigmentosum was reported to have a basal cell carcinoma (BCC) diagnosed at the age of 15 years. Fifty-nine of cIGHD patients had been treated with hGH, including the boy who developed BCC. Out of the 79 patients with GHRHR mutations (12 previously treated with $\mathrm{hGH}$ ), three had cancer (one of them previously treated with hGH) and so had three out of 113 patients with cMPHD. In the latter group, 97 had been previously treated with hGH, in addition to other hormone replacement therapy, and among them, two had developed malignancies.

Out of 752 first-degree relatives, 26 reported 30 instances of cancer $(P=0.019)$ and out of 131 further relatives, 30 reported 31 instances of cancer $(P<0.001)$. Nine malignancies were reported in eight of the siblings $(P=0.165)$. In Table 3 , it is evident that the majority are lung, breast and prostate cancer, followed by colon and gastric cancer.

\section{Discussion}

In this attempt of a worldwide survey of the prevalence of cancer in patients with secondary congenital IGF1 deficiency, we confirmed and enlarged our preliminary observation that patients with LS, having both congenital GH and IGF1 deficiency and insensitivity to endogenous and exogenous GH, seem protected from the development of cancer (13). That observation was also confirmed by findings in the large Ecuadorian cohort of LS patients (15). Considering that the latter cohort accounts for 100 living patients, it is obvious that over 300 patients with LS, the majority now being adults, have not developed cancer.

In contradistinction, 15 of their 218 first-degree relatives in the present survey and 24 out of 131 further relatives (proven or supposed heterozygotes for the disease) reported 43 instances of cancer. The difference between presence or absence of malignancy between patients with LS and their first-degree relatives and siblings was statistically significant $(P<0.001$, $P=0.005$, respectively). In the Ecuadorian cohort, 80 out of 1032 relatives died of cancer (15).

Only one boy out of 116 patients with congenital IGHD presented a BCC of the cheek. This patient also suffered from xeroderma pigmentosum, a genetic defect 
Table 3 Types of cancer reported in first and further-degree relatives of patients with congenital insulin-like growth factor 1 deficiency.

\begin{tabular}{|c|c|c|}
\hline Type of cancer & $\begin{array}{l}\text { Number (age at } \\
\text { diagnosis in years) }\end{array}$ & $\begin{array}{l}\text { Diagnosis of } \\
\text { probands }\end{array}$ \\
\hline Lung & $9(48-72)$ & $\begin{array}{l}7 \text { LS, } 1 \text { IGHD, } 1, \\
\text { MPHD }\end{array}$ \\
\hline Breast & $7(45-75)$ & 5 LS, 2 IGHD \\
\hline Prostate & $7(40-76)$ & $6 \mathrm{LS}, 1 \mathrm{IGHD}$ \\
\hline Colon & $6(58-63)$ & 3 LS, 3 IGHD \\
\hline Gastric & 6 (43, unk.) & $\begin{array}{l}4 \text { LS, } 1 \text { IGHD, } 1 \\
\text { MPHD }\end{array}$ \\
\hline Leukemia & $4(3-84)$ & $\begin{array}{r}2 \text { LS, } 1 \text { MPHD, } 1 \\
\text { GHRHR defect }\end{array}$ \\
\hline Unknown primary & 4 (unk.) & 3 LS, 1 IGHD \\
\hline Pancreas & $2(54,73)$ & $1 \mathrm{LS}, 1 \mathrm{MPHD}$ \\
\hline Uterus & 2 (48, unk.) & 2 LS \\
\hline Bone & $2(17$, unk.) & $1 \mathrm{IGHD}, 1 \mathrm{MPHD}$ \\
\hline Lymphoma & 2 (62, unk.) & $1 \mathrm{IGHD}, 1 \mathrm{MPHD}$ \\
\hline Nose & 1 (unk.) & $1 \mathrm{LS}$ \\
\hline Renal & 1 (unk.) & 1 LS \\
\hline Thyroid & $1(25)$ & $1 \mathrm{LS}$ \\
\hline SCC & $1(65)$ & $1 \mathrm{LS}$ \\
\hline Brain & $2(4,56)+1$ susp. $(13)$ & 2 LS (susp. - MPHD) \\
\hline Liver & 1 (unk.) & $1 \mathrm{LS}$ \\
\hline Esophagus & 1 (unk.) & $1 \mathrm{LS}$ \\
\hline Bladder & $1(81)$ & $1 \mathrm{LS}$ \\
\hline Testis & 1 (unk.) & 1 LS \\
\hline Total & 61 malig. + 1 susp. & \\
\hline
\end{tabular}

UNK, unknown

involving DNA repair. Out of the 79 patients with GHRHR mutation and 113 with congenital MPHD, six instances of cancer were reported, three with previous hGH treatment.

The lack of complete protection against cancer in the patients with GHRHR mutations and those with congenital MPHD could be due either to the fact that some patients still secrete small amounts of GH (16), that some are sensitive to the exogenously administered hGH treatment or other environmental noxae and/or belonging to a familial genetic trend for malignancy.

The fact that heterozygote family members, which secrete IGF1 and/or hGH, develop malignancies, in a relatively high incidence for the given ethnic groups, may favor the above assumption. It is also of note that the types of malignancies and their prevalence in our study group correspond to the prevalence in the overall population (17).

The difference in age range between the patients who did not develop cancer and the family members who developed cancer may be considered to influence our conclusions, although our own cohort of 67 LS and 28 cIGHD patients consists almost entirely of adult patients, pointing to the fact that age may be a confounding factor but not the major factor in the development of cancer. Comparing our data with the incidence of cancer in Israel and neighboring countries, it is evident that the incidence in the age group 0-19 years is $10 \%$ of that occurring in the age group 20-49 years. In these populations, breast cancer is diagnosed as early as 15 years (The web site of the Israeli National Cancer Registry, www.health.gov.il/icr).
The present reported clinical data is supported by recent animal experiments which prove that the homozygous GHR-KO-mouse $(18,19)$ exhibits statistically significant reductions in the overall incidence of malignancy (20-22). An earlier experimental study also revealed that $\mathrm{dw} / \mathrm{dw}$ rats, congenitally deficient in $\mathrm{GH}$, are resistant to dimethylbenzathracene (DMBA)induced mammary carcinoma (23).

It is of interest that animal experiments with cMPHD mice (Ames and Snell) have shown different degrees of protection against malignancies. While the Snell mice exhibit significant protection against the development of cancer (24), the Ames mice are not different from their litter mates regarding the prevalence of malignancies, but develop the cancer at an older age (25). This resembles our data in man and is possibly due to the secretion of small amounts of GH. Further support for our hypothesis that IGF deficiency tends to protect against cancer is the successful use in oncology of IGF1R-blocking drugs (12).

In conclusion, our findings bear heavily on the relationship between GH/IGF1 and cancer. Follow-up of the homozygous patients with congenital IGF1 deficiency and insensitivity to GH will show whether they are protected from future cancer development, even if treated with IGF1. Patients with congenital IGHD, nowadays treated with hGH in most countries, also seem protected (the only instance of cancer reported needs further clarification).

The secretion of small amounts of endogenous GH/IGF1 such as that shown in few patients with GHRHR mutation or with congenital MPHD, as well as their normal secretion in heterozygous carriers of LS or IGHD gene defects, may play a role in the development of cancer in these patients.

\section{Declaration of interest}

The authors declare that there is no conflict of interest that could be perceived as prejudicing the impartiality of the research reported.

\section{Funding}

This research was part of the Thesis of R Steuerman as part of the requirements toward the MD degree at the Sackler Faculty of Medicine, Tel-Aviv University.

\section{Acknowledgements}

We are indebted to the following colleagues for providing data on their patients: Gianluca Aimareti, Italy; A Akinci, Turkey; Ivo Arnhold, Brazil; Simon Attard-Montalto, Malta; B Ayudant, Peru; Maryam Razzaghy Azar, Iran; Carlos Ben-Basat, Israel; Merih Berberoglu, Turkey; Carla Bizzari, Italy; Gianfranco F Bottazo, Italy; George Bright, USA; Thierry Brue, France, Atilla Buyukgebitz, Turkey; Marco Cappa, Italy; Luciani Carvalho, Brazil; Fernando Cassorla, Chile; Shelly Chen, China; Amnon Cohen, Italy; Chris Cowell, Australia; Patricia Crock, Australia; Feyza Darendeliler, Turkey; Filippo De Luca, Italy; Carlo De Sanctis, Italy; Liat De-Vries, Israel; Alon Eliakim, Israel; Mohamed El Kholy, Egypt; Betul Ersoy, Turkey; Angel Ferrandez Longas, Spain; Herwig Frisch, Austria; Vivian Gallardo, Chile; Assimina 
Galli-Tsinopoulou, Greece; Ezio Ghigo, Italy; Rachel Gurevich, Israel; Elke Hammer, Germany; Fatima Harun, Malaysia; Harry Hirsch, Israel; Ali Hojjat, UK; Reiko Horikawa, Japan; Vivian Hwa, USA; Lourdes Ibanez, Spain; Keiji Iida, Japan; Alexander Jorge, Brazil; Alexandra Keller, Germany; Ciril Krzisnik, Slovenia; Banu Kucukemre, Turkey; Angelico Lampis, Italy; Liora Lazar, Israel; Kwok Leung, Hong Kong; Yael Levental-Bendor, Israel; Yehuda Limoni, Israel; Mare Maes, Belgium; Manuel Herminio Aguiar-Oliviera, Brazil; Alicia Martinez, Argentina; Maria Francesco Messina, Italy; Dalit Modan, Israel; Primus Mullis, Switzerland; Osamu Nose, Japan; Oswaldo Nunez, Peru; Zerrin Orbak, Turkey; Alev Ozon, Turkey; Magdalena Paskova, Slovakia; Moshe Phillip, Israel; K Pichestin, Thailand; Mariana Rachmiel, Israel; Yardena Rakover-Tennenbaum, Israel; Ron Rosenfeld, USA; Roberto Salvatori, USA; Jeerunda Santiprabhob, Thailand; Lars Savendahl, Sweden; Antonio Selman, Santo Domingo; Stephan Shalet, UK; Shuixian Shen, China; Ivani Novato Silva, Brazil; Phyllis Speiser, USA; Maithe Tauber, France; Svetlana Ten, USA; M Tibi, Israel; Dov Tiosano, Israel; Rahim Vakili, Iran; M Vera, Cuba; J Vesterhus, Norway; Saria Wakim, Lebanon; Marie-Jose Walenkamp, Netherlands; Hartmut Wollmann, Germany; N Yordam, Turkey; Stefano Zucchini, Italy. We also wish to acknowledge Mrs Pearl Lilos for her assistance in the statistical calculations.

\section{References}

1 Pandey V, Perry JK, Mohankumar KM, Kong XJ, Liu SM, Wu ZS, Mitchell MD, Zhu T \& Lobie PE. Autocrine human growth hormone stimulates oncogenicity of endometrial carcinoma cells. Endocrinology 2008149 3909-3919. (doi:10.1210/en.2008-0286)

2 Dardenne M, Smaniotto S, de Mello-Coelho V, Villa-Verde DM \& Savino W. Growth hormone modulates migration of developing T cells. Annals of the New York Academy of Sciences 20091153 1-5. (doi:10.1111/j.1749-6632.2008.03977.x)

3 Furstenberger G \& Senn HJ. Insulin like growth factors and cancer. Lancet Oncology 20023 298-302. (doi:10.1016/S1470-2045 (02)00731-3)

4 Frasca S, Pandini G, Sciacci L, Pezzino V, Squatrito S, Belfiore A \& Vigneri R. The role of insulin receptors and IGF-I receptors in cancer and other diseases. Archives of Physiology and Biochemistry 2008114 23-37. (doi:10.1080/13813450801969715)

5 Pollak MN. Insulin like growth factors and neoplasia. In Biology of IGF-I: Its Interaction with Insulin in Health and Malignant States, pp 84-107. Chichester: Wiley, Novartis foundation symposium 262, 2004.

6 Balamuth NJ \& Womer RB. Ewing's sarcoma. Lancet Oncology 201011 184-192. (doi:10.1016/S1470-2045(09)70286-4)

7 Natrajan R, Reis-Filho JS, Little SE, Messahel B, Brundler MA, Dome JS, Grundy PE, Vujanic GM, Pritchard-Jones K \& Jones C. Blastemal expression of type I insulin-like growth factor receptor in Wilms' tumors is driven by increased copy number and correlates with relapse. Cancer Research $2006 \mathbf{6 6} 11148-11155$. (doi:10.1158/0008-5472.CAN-06-1931)

8 Houghton PJ, Morton CL, Gorlick R, Kolb EA, Keir ST, Reynolds CP, Kang MH, Maris JM, Wu J \& Smith MA. Initial testing of a monoclonal antibody (IMC-A12) against IGF1R by the pediatric preclinical testing program. Pediatric Blood and Cancer $2010 \mathbf{5 4} 921-926$. (doi:10.1002/pbc.22367)

9 Eshet R, Werner H, Klinger B, Silbergeld A, Laron Z, Leroith D \& Roberts CT. Up-regulation of insulin-like growth factor-I (IGF-I) receptor gene expression in patients with reduced serum IGF-I levels. Journal of Molecular Endocrinology 199310 115-120. (doi:10.1677/jme.0.0100115)

10 Werner H \& LeRoith D. The insulin-like factor-I receptor signaling pathways are important for tumorigenesis and inhibition of apoptosis. Critical Reviews in Oncology/Hematology 19978 71-92.

11 Werner H. The pathophysiological significance of IGF-I receptor overexpression: new insights. Pediatric Endocrinology Reviews 2009 $72-5$.
12 Atzori F, Traina TA, Ionta MT \& Massidda B. Targeting insulin-like growth factor type 1 receptor in cancer therapy. Targeted Oncology 20094 255-266. (doi:10.1007/s11523-009-0123-z)

13 Shevah $\mathrm{O} \&$ Laron Z. Patients with congenital deficiency of IGF-I seem protected from the development of malignancies: a preliminary report. Growth Hormone and IGF Research 200717 54-57. (doi:10.1016/j.ghir.2006.10.007)

14 BMDP statistical software. Eds WJ Dixon. Los Angeles: University of California press, 1993.

15 Guevara-Aguirre J, Guevara-Aguirre M, Saavedra J \& Bernstein G. Low serum levels of IGF-I, BP3 and ALS are associated to severe short stature, obesity, premature aging, increased cardiovascular mortality and absence of cancer in the ecuadorian cohort of Laron syndrome subjects. Hormone Research 200768 (Supplement 1) 175.

16 Aguiar-Oliveira MH, Oliveira FT, Pereira RMC, Oliveira CRP, Blackford A, Valenca EHO, Santos EG, Gois-Junior MB, MeneguzMoreno RA, Araujo VP, Oliveira-Neto LA, Almeida RP, Santos MA, Farias NT, Silveira DCR, Cabral GW, Calazans FR, Seabra JD, Lopes TF, Rodrigues EO, Porto LA, Oliveira IP, Melo EV, Martari M \& Salvatori R. Longevity in untreated congenital growth hormone deficiency due to a homozygous mutation in the GHRH receptor gene. Journal of Clinical Endocrinology and Metabolism 201095 714-721. (doi:10.1210/jc.2009-1879)

17 Longo DL. Approach to the patient with cancer. In Harrison's Principles of Internal Medicine, 17th edn, vol 1, ch 77, pp 479-486. Eds AS Fauci, E Braunwald, DL Kasper, SL Hauser, DL Longo, JL Jameson \& J Loscalzo, 2008.

18 Zhou Y, Xu BC, Maheshwari HG, He L, Reed M, Lozykowski M, Okada S, Cataldo L, Coschigamo K, Wagner TE, Baumann G \& Kopchick JJ. A mammalian model for Laron syndrome produced by targeted disruption of the mouse growth hormone receptor/ binding protein gene (the Laron mouse). PNAS $1997 \mathbf{9 4}$ 13215-13220. (doi:10.1073/pnas.94.24.13215)

19 Kopchick JJ \& Laron Z. Is the Laron mouse an accurate model of Laron syndrome? Molecular Genetics and Metabolism 199968 232-236. (doi:10.1006/mgme.1999.2890)

20 Wang Z, Prins GS, Coschigano KT, Kopchick JJ, Green JE, Ray VH, Hedayat S, Christov KT, Unterman TG \& Swanson SM. Disruption of growth hormone signaling retards early stages of prostate carcinogenesis in the C3(1)/T antigen mouse. Endocrinology 2005 146 5188-5196. (doi:10.1210/en.2005-0607)

21 Ikeno Y, Hubbard GB, Lee S, Cortez LA, Lew CM, Webb CR, Berryman DE, List EO, Kopchick JJ \& Bartke A. Reduced incidence and delayed occurrence of fatal neoplastic diseases in growth hormone receptor/binding protein knockout mice. Journals of Gerontology. Series A, Biological Sciences and Medical Sciences 2009 64 522-529. (doi:10.1093/gerona/glp017)

22 Bower BD \& Kopchick JJ. Cancer. In Laron Syndrome from Man to Mouse, ch 57, pp 495-506. Eds Z Laron \& JJ Kopchick. Heidelberg, London, New-York: Springer Verlag, 2010.

23 Ramsey MM, Ingram RL, Cashion AB, Ng AH, Cline JM, Parlow AF \& Sonntag WE. Growth hormone-deficient dwarf animals are resistant to dimethylbenzanthracine (DMBA)-induced mammary carcinogenesis. Endocrinology 2002143 4139-4142. (doi:10. 1210/en.2002-220717)

24 Alderman JM, Flurkey K, Brooks NL, Naik SB, Srinivas U, Ziara KB, Jung L, Boysen G, Bronson R, Klebanov S, Chen X, Swenberg JA, Stridsberg M, Parker CE, Harrison DE \& Combs TP. Neuroendocrine inhibition of glucose production end resistance to cancer in dwarf mice. Experimental Gerontology 200944 26-33. (doi:10. 1016/j.exger.2008.05.014)

25 Ikeno Y, Bronson RT, Hubbard GB, Lee S \& Bartke A. Delayed occurrence of fatal neoplastic diseases in ames dwarf mice: correlation to extended longevity. Journals of Gerontology. Series A, Biological Sciences and Medical Sciences 200358 B291-B296. (doi:10.1093/gerona/58.4.B291)

Received 29 December 2010

Accepted 3 February 2011 